\title{
慢性中耳炎に抢忷る感音難聴の検討
}

\author{
黒木 岳人・伊藤 信輔・小田原修一・山口 勝矢 \\ 平木 基裕・井立 睦子・武富 正夫・徳丸 久子
}

\section{Sensorineural Hearing Loss in Chronic Otitis Media}

\author{
Taketo Kuroki, Shinsuke Ito, Shuichi Odahara, Katsuya Yamaguchi, \\ Motohiro Hiraki, Mutsuko Idate, Masao Taketomi and Hisako Tokumaru \\ (Kurume University)
}

The incidence and degree of sensorineural hearing loss were analyzed in 303 patients with monolateral chronic otitis media. The contralateral healthy ear served as a control. A difference greater than $10 \mathrm{~dB}$ in average of bone conduction thresholds at $500,1000,2000$ and $4000 \mathrm{~Hz}$ was found in $30 \%$ of the subjects, $20 \mathrm{~dB}$ in $16 \%$ and $30 \mathrm{~dB}$ in $5 \%$. Each frequency was equally affected. Patients with prolonged disease were more likely to be affected. Significant relationship was not found between sensorineural hearing loss and the presence of cholesteatoma.

Key words: bone conduction threshold, otitis media, cholesteatoma

はじめに

慢性中耳炎による内耳の障害についての報告 は古くより行なわれて抮り, Gardenghi (1955) ${ }^{1)}$ は慢性中耳炎例の $42 \%$ に感音難聴が認められた

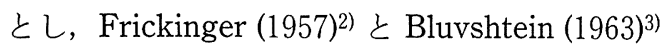
も慢性中耳炎に続発した感音難聴の頻度につい て同様の報告を行なっている。さらに Paparella ら (1970)4) は, 耳漏や肉芽を伴った慢 性中耳炎例では，それらを伴わない例より内耳 の障害は著しく, 障害の度は罹病期間とも関連 があると述べている。 その後も類似の報告 (English ら, 19735), Tos, 19886), Levine ら, 19897), Cusimano ら，19898))が行なわれて扣り, Morizono ら (1985) $)^{9)}$ は動物実験でも化膿性中 耳炎が感音難聴を引き起こしたことを報告して いる。 しかし一方では, 慢性中耳炎による内耳
障害を否定する報告 (Dumich ら， 198310), Walby ら, 198311), Browning と Gatehouse, 198912) も行なわれて拈り, 慢性中耳炎が内耳 の障害を招くか否かについてはな㩘論がある. 本論文では我々の取り扱った慢性中耳炎症例 を対象として感音難聴の頻度と度合いを調べ, それが音域，中耳炎の罹病期間，真珠腫の有無 によって違いがあるか否かを検討した。

\section{対象と方法}

1981年から1990年までの10年間に久留米大学 医学部耳鼻咽喉科を受診した慢性中耳炎患者 1216名のらち，一側性の中耳炎で対側耳の聴力 が同年齢に拈ける平均を越えていなかった 303 例を対象にした。患耳に迷路㾞孔を認めた例と 手術の既往のある例は除外した. 中耳炎の初発 時期はすべて小児期であったが，ほとんどの例 
でその正確な年齢を知ることはできなかった。

上記を対象として500，1000，2000，4000 Hz の患耳の平均骨導聴力を健耳のそれと比較した. すなわち平均值の左右差, 周波数別の左右差を 調べた.ささら平均値の左右差の度合いが年齢 と関係するか否か，また真珠腫の有無と関係す るか否かについても検討した.

\section{結 果}

1. 平均骨導聴力の左右差

骨導聴力レベルの 6 分法による平均值が健耳 に比べて $10 \mathrm{~dB}$ 以上大きい例は，表 1 に示すよ らに90例（30\%）であった。またその差が 20 $\mathrm{dB}$ 以上の例は 49 例 (16\%), $30 \mathrm{~dB}$ 以上の例は 14例（5\%）であった.

2 . 周波数と骨導聴力の左右差

骨導值を周波数別に患耳と健耳とを比較した 結果, 図 1 に示すように, $10 \mathrm{~dB}$ 以上の差が認
められたのは, $500 \mathrm{~Hz}$ では $30 \%, 1000 \mathrm{~Hz}$ で は33\%，2000 Hz では $38 \% ， 4000 \mathrm{~Hz}$ では31\% で,すべての周波数の間で感音難聴の発生頻度 に差はなかった。また $20 \mathrm{~dB}$ 以上あるいは 30 $\mathrm{dB}$ 以上の左右差が認められた例の頻度につい ても同様であった.

3 . 年齢と平均骨導聴力の左右差

年齢との関係を調べるために, 年代別に検討

表 1 平均骨導聴力の左右差とその頻度 $(\mathrm{n}=303)$

\begin{tabular}{c|r|r}
\hline \hline 骨導值 $(6$ 分法平均 $)$ & $\mathrm{n}$ & $\%$ \\
の左右差 $(\mathrm{dB})$ & 213 & 70 \\
$<10$ & 90 & 30 \\
$10 \leqq$ & 49 & 16 \\
$20 \leqq$ & 14 & 5 \\
$30 \leqq$ & &
\end{tabular}

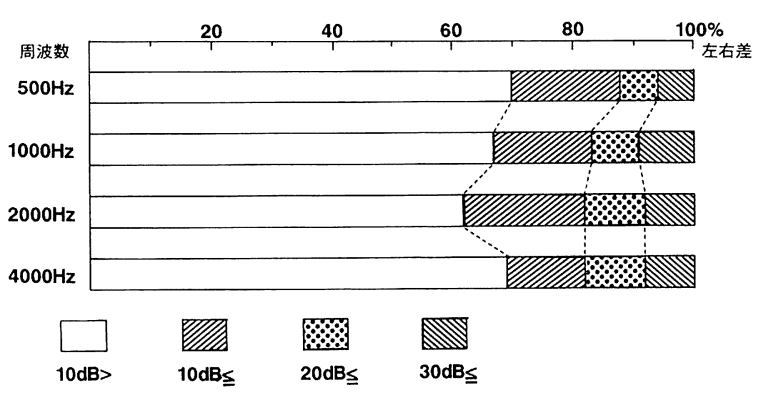

図 1 周波数と骨導聴力の左右差 $(n=303)$

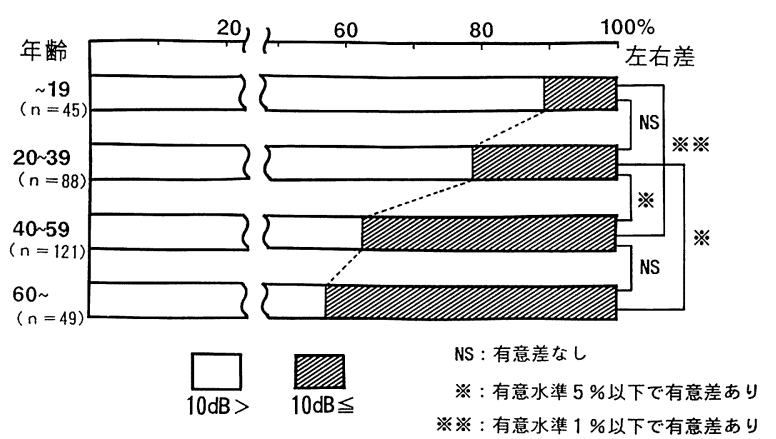

図 2 年齢と骨導聴力（6 分法平均）の左右差 
した結果は, 図 2 に示すように, $10 \mathrm{~dB}$ 以上の 左右差が認められたのは，19歳までの例では11 \%，20歳から39歳までの例では $23 \% ， 40$ 歳から 59 歳までの例では $36 \% ， 60$ 歳以上の例では $43 \%$ と，年齢が高くなるのに従い感音難聴を伴う頻 度が増大する傾向が認められた， $\chi^{2}$ 検定によ って，19歳までの群と20歳から39歳までの群の 間には有意差はなかったが，20歳から39歳まで の群と40歳から59歳までの群の間には有意水準 5\%以下で差が認められた。また19歳までの群 と40歳から59歳までの群の間には有意水準 $1 \%$ 以下で差が認められ，20歳から39歳までの群と 60 歳以上の群の間にも有意水準 $5 \%$ 以下で差が 認められた。

図 3 に示すよらに, $20 \mathrm{~dB}$ 以上の左右差を呈 する症例の占める割合についても, 経過期間が 長くなるのに従い増大する傾向が認められた. $\chi^{2}$ 検定によって，19歳までの群と20歳から39
歳までの群の間には有意差はなかったが，20歳 から39歳までの群と40歳から59歳まての群の間 には有意水準 $5 \%$ 以下で差が認められた。また 19歳までの群と40歳から59歳までの群の間には 有意水準 $1 \%$ 以下で差が認められ，20歳から39 歳までの群と60歳以上の群の間にも有意水準 1 \%以下で差が認められた.

図 4 に示すように，30 dB 以上の左右差を呈

表 2 平均骨導聴力の左右差と真珠腫の有無 $(\mathrm{n}=303)$

\begin{tabular}{c|r|r|r|r}
\hline \hline \multirow{2}{*}{$\begin{array}{l}\text { 骨導值 }(6 \text { 分法平均 }) \\
\text { の左右差 }(\mathrm{dB})\end{array}$} & \multicolumn{2}{|c|}{$\begin{array}{c}\text { 真珠腫 : 有 } \\
\mathrm{n}=59\end{array}$} & \multicolumn{2}{|c}{$\begin{array}{c}\text { 真珠腫 : 無 } \\
\mathrm{n}=244\end{array}$} \\
\cline { 2 - 5 } & \multicolumn{1}{|c|}{$\mathrm{n}$} & $\%$ & \multicolumn{1}{c|}{$\mathrm{n}$} & $\%$ \\
\hline$<10$ & 39 & 66 & 174 & 71 \\
$10 \leqq$ & 20 & 34 & 70 & 29 \\
$20 \leqq$ & 6 & 10 & 43 & 18 \\
$30 \leqq$ & 4 & 7 & 10 & 4
\end{tabular}

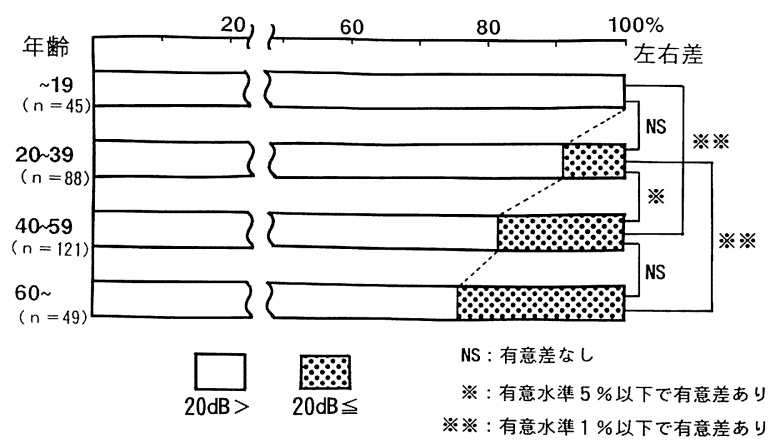

図 3 年齢と骨導聴力（6 分法平均）の左右差

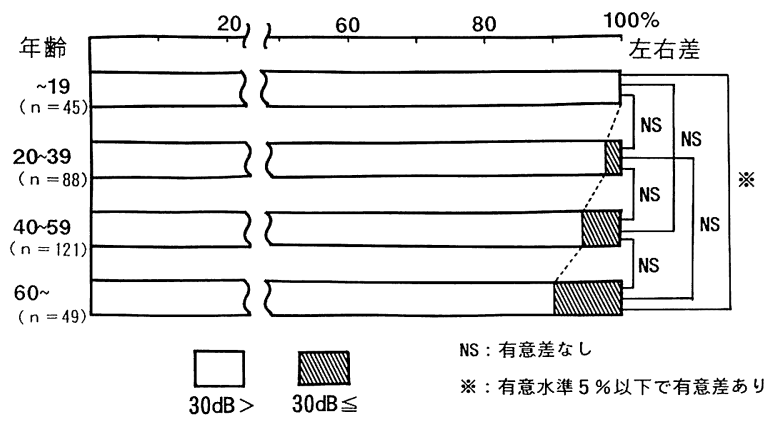

図 4 年齢と骨導聴力（6 分法平均）の左右差 
した症例の占める割合については，19歳までの 群と60歳以上の群の間に有意水準 $5 \%$ 以下で差 が認められたが，それ以外の年代別の比較では 差は認められなかった。

4. 真珠腫の有無と平均骨導聴力の左右差 真珠腫の存在と感音難聴の発症との関係を調 べた結果は，表 2 に示すように, $10 \mathrm{~dB}$ 以上の 左右差が認められたのは, 真珠腫の有った例の 34\%，無かった例の29\%で頻度に差はなかった. また $20 \mathrm{~dB}$ 以上あるいは $30 \mathrm{~dB}$ 以上の左右差を 呈した頻度についても差はなかった。

\section{考察}

慢性中耳炎が内耳の障害を招くか否かについ ては，はじめに述べたよらに，報告者によって 意見が分かれる．我々が調査の対象にした一側 性の慢性中耳炎症例では，正確な罹病期間を割 り出すことはできなかったが，発病したのはす べて小児期であったので，診察時の年齢がほぼ それに近いとみなすことができる。したがって 今回得られた結果から, 発症後経過が長くなる に従い，骨導聴力が低下寸る頻度が高くなるこ とが推察され, 中耳の炎症は長い経過で内耳に 障害を及ぼすことが示唆された.

骨導聴力の低下は伝音機構の障害によっても 引き起こされるので，その低下の寸べてが内耳 の障害を反映するものではないが，Carhart (1950)13) の効果を考慮に入れて， $500 \mathrm{~Hz} ， 1000$ $\mathrm{Hz}, 2000 \mathrm{~Hz}, 4000 \mathrm{~Hz}$ における骨導聴力から それぞれ $5 \mathrm{~dB}, 10 \mathrm{~dB}, 15 \mathrm{~dB}, 5 \mathrm{~dB}$ を差し引く としても, その平均值は 6 分法で $10 \mathrm{~dB}$ であり, 骨導聴力の平均值の左右差が $10 \mathrm{~dB}$ 以上の場合 には内耳が障害されているとみなしてよいよう に考えられる。 ちなみに Gatehouse ら (1982) ${ }^{14)}$ が最近 Carhart の効果を再検討した結果によれ ば, $500 \mathrm{~Hz}$ では $5 \mathrm{~dB}, 1000 \mathrm{~Hz}$ では $8 \mathrm{~dB}, 2000 \mathrm{~Hz}$ では $12 \mathrm{~dB}, 4000 \mathrm{~Hz}$ では $5 \mathrm{~dB}$ としており，い ずれもCarhart の報告した值に近く，その 6 分 法による平均值は $8.3 \mathrm{~dB}$ で, $10 \mathrm{~dB}$ に満たな い.

慢性中耳炎の経過と内耳障害の頻度の間に関
連があることが明らかにされたが，内耳の障害 の度合いも疾患の経過と関係することが示唆さ れた. 寸なわち経過が短い例より長い例の方が $20 \mathrm{~dB}$ 以上あるいは $30 \mathrm{~dB}$ 以上の左右差を呈寸 る率が高かった。この事実も中耳炎と内耳障害 の因果関係を示すものと考兄られる.

慢性中耳炎に対する手術治療の主目的は現症 の改善にあるが，今回得られた結果から, 感音 難聴の予防をそれに加えることは妥当と考えら れた。すなわち中耳炎症例に対しては，たと兄 耳漏や難聴の訴えがない場合でも若い間に手術 治療を行なった方が良いと思われる.

\section{まとめ}

1981年から1990年までの 10 年間に久留米大学 医学部耳鼻咽喉科を受診した303例の一側性慢 性中耳炎について骨導聴力を健耳と比較し，次 のような結果を得た。

1. 6 分法による平均值の左右差が $10 \mathrm{~dB}$ 以 上の例は 90 例 $(30 \%), 20 \mathrm{~dB}$ 以上の例は 49 例 $(16 \%), 30 \mathrm{~dB}$ 以上の例は14例（5\%）であっ た。

2. 慢性中耳炎の罹病期間が長くなるに従い 感音難聴を伴う頻度が高くなり，その度合いが 大きくなる傾向が認められた。

3 . 周波数別には感音難聴の発症頻度に差は なかった。

4. 真珠腫の有無によって感音難聴の発症頻 度に差はなかった。

\section{文献}

1) Gardenghi $G$ : Conttriburo allo studio della fusione cocleare nell'otite media purulenta cronica. Boll Mal Orench 73 : 587 606, 1955.

2) Frickinger $A:$ Die Häufigkeit der Innenohrbeteiligung bei den genuin chronischen Entzündungen des Mittelohres. Hals Nasen Ohrenheilkd 6 : 240 243, 1957.

3) Bluvshtein GM : Audioligischeskaia kharakteristika khronicheskikh gnoinykh srednikh otitov. Vestn Otorhinolaringol 25:64 72, 1963.

4) Paparella MM, Brady DR and Hoel R : Sen- 
sorineural hearing loss in chronic otitis media and mastoiditis. Trans Am Acad Ophthalmol Otolaryngol $74: 108 \sim 115,1970$.

5) English GM, Northern JL and Fria TJ : Chronic otitis media as a cause of sensorineural hearing loss. Arch Otolaryngol 98: 18 22, 1973.

6) Tos $M$ : Sensorineural hearing loss in acute and chronic middle ear diseases. Acta Otolaryngol (Stockh) Suppl $457:$ 87 93, 1988.

7) Levine BA, Shelton C, Berliner KI, et al : Sensorineural loss in chronic otitis media. Arch Otolaryngol Head Neck Surg 115 : 814 816, 1989.

8) Cusimano F, Cocita VC and D'Amico A : Sensorineural hearing loss in chronic otitis media. J Laryngol Otol $103:$ 158 163, 1989.

9) Morizono T, Giebink S, Paparella MM, et al : Sensorineural hearing loss in experimental purulent otitis media due to streptococcus pneumoniae. Arch Otolaryngol 111 : 794 798,
1985.

10) Dumich PS, Harner SG and Rochester MN : Cochlear function in chronic otitis media. Laryngoscope 93 : 583 586, 1983.

11) Walby AP, Barrea A and Schuknecht HF : Cochlear pathology in chronic suppurative otitis media. Ann Otol Rhinol Laryngol 92 suppl $103:$ 3 19, 1983.

12) Browning GG and Gatehouse $S$ : Hearing in chronic suppurative otitis media. Ann Otol Rhinol Laryngol 98 : 245 250, 1989.

13) Carhart $R:$ Clinical application of bone conduction audiometry. Arch Otolaryngol 51 : 798 908, 1950.

14) Gatehouse $S$, Browning GG : A reexamination of the Carhart effect. Br J Audiol $16: 215 \sim 220$, 1982.

(別刷請求先 : 黒木岳人 干830 久留米市旭町 67

久留米大学医学部耳鼻咽喉科学教室) 